Fazileta Hafizović

\section{Popis sela i zemlje sandžaka Krka, Klis i Hercegovina, oslobođenih od Mletačke Republike 1701. godine}

\begin{abstract}
Zagreb - Sarajevo: Srpsko kulturno društvo »Prosvjeta « - Centar za komparativnohistorijske i interkulturne studije Filozofskog fakulteta Sveučilišta u Zagrebu Orijentalni institut u Sarajevu, 2016, 534 str.
\end{abstract}

DOI: https://doi.org/10.11567/met.33.2.6

Prema ugovoru o razgraničenju Osmanskog Carstva i Mletačke Republike nakon Morejskog rata, Mletačka je Republika 1701. vratila Osmanskom Carstvu teritorij koji je bila zauzela u tom ratu - dio sandžaka Krka, Klis i Hercegovina. Kritičko izdanje deftera (katastarskoga poreznog popisa koji sadržava podatke o naseljima, kućanstvima, stanovništvu, zemljištima i sl.) sastavljenog 1701./1702., u kojem je popisan vraćeni teritorij, djelo je osmanistice iz Orijentalnog instituta u Sarajevu Fazilete Hafizović, a objavljeno je 2016. u izdanju Srpskoga kulturnog društva »Prosvjeta«, Centra za komparativnohistorijske i interkulturne studije Filozofskog fakulteta Sveučilišta u Zagrebu i Orijentalnog instituta u Sarajevu. Defter, koji ima 160 stranica, čuva se u Arhivu Predsjedništva Vlade (Başbakanlık Osmanlı Arşivi) u Istanbulu, pod brojem TTD No. 861. Defter je preveden i obrađen $\mathrm{u}$ okviru projekta Naučnoistraživački rad u oblasti opće (društvene, političke, ekonomske i vojne) historije Bosne i Hercegovine $u$ doba osmanske uprave Orijentalnog instituta u Sarajevu, a objavljen je u biblioteci Izvori SKD-a »Prosvjeta«, čiji je prvi svezak bio još jedan protostatistički izvor s početka 18. stoljeća Popis Like i Krbave 1712. godine, objavljen 2003.
Uvodni tekst Fazilete Hafizović (str. 7-12) opisom političke i vojne situacije u 17. stoljeću donosi povijesni kontekst nastanka deftera. Autorica opisuje sam defter te ukratko donosi njegov sadržaj, odnosno pregled elemenata koji su u njemu popisani.

Sam defter (str. 13-492) donosi popis prema nahijama, unutar kojih se popisuju sela. Susreću se i novoformirane nahije, a među njima i one koje su samo privremene, te je stoga njihovo spominjanje u ovom defteru njihovo jedino poznato spominjanje $u$ povijesnim izvorima. Popisani su svi kućedomaćini, iz čega se vidi da su mnoga sela pusta, ponekad s tek nekoliko kuća, a neka su i potpuno napuštena. Ratna su stradanja učinila svoje, a $\mathrm{u}$ južnijim je krajevima prisutno i višedesetljetno pljačkanje crnogorskih razbojnika. Popisani su i vlasnici posjeda, a pritom je zabilježeno jesu li živi te jesu li prisutni ili su se odselili. Dio posjednika prešao je na kršćansku stranu (što se veže uz aktivnu politiku Mletačke Republike usmjerenu slabljenju demografske baze Osmanskog Carstva), dio se odselio u druge dijelove Osmanskog Carstva, a dio je još uvijek zarobljen te radi na mletačkim lađama. U defteru je detaljno bilježena i raspodjela prihoda vojnoj klasi. Popisuju se i različiti objekti - kule, mostovi, džamije, crkve, mlinovi, stupe i sl. Na taj način saznajemo i o materijalnim štetama nakon rata. Udio objekata koji su u ruševnom stanju zaista je velik. Zanimljivo je da su popisane džamije pretežno u ruševnu stanju, dok su crkve pretežno u ispravnu stanju. Manji dio popisanih crkava i džamija do sada je bio potpuno nepoznat jer nisu sačuvane, a ne spominju se $u$ drugim izvorima. 
U pogovoru Drago Roksandić (str. 493-496) donosi prikaz dugogodišnjih nastojanja oko kritičkog objavljivanja predmetnog deftera. Ideja za njegovo kritičko izdanje rodila se još 1999 . u sklopu projekta Triplex Confinium: jedan od njegovih ciljeva bilo je izdavanje protostatističkih popisa stanovništva prostora habsburško-mletačkoosmanskog trograničja. Kao što je već navedeno, prvi je korak $\mathrm{u}$ tome bilo objavljivanje Popisa Like i Krbave 1712. godine, a objavljivanje ovog deftera daljnji je korak $\mathrm{u}$ ispunjavanju projektnih ciljeva. U vezi s time Drago Roksandić ističe i nužnost objavljivanja mletačkih popisa prostora trograničja s početka 18. stoljeća kako bi se dobila zaokruženija slika situacije u razdoblju nakon potpisivanja mira u Srijemskim Karlovcima.

$\mathrm{Na}$ kraju knjige nalaze se dva defteru suvremena zemljovida istočnojadranskog prostora, kazalo geografskih pojmova (str. 497-510), zemljovid osmansko-mletačke granice na istočnom Jadranu nakon mira u Srijemskim Karlovcima s novom upravnom podjelom nahija Hercegovačkog sandžaka (str. 498-499), popis izvora i literature (str. 511-517) i bilješka o autorici (str. 519).

Vrijednost ovoga kritičkog izdanja ogleda se u mnogo aspekata. Objavljivanjem arhivske građe povjesničarima se značajno olakšava posao, a u slučaju ovog izdanja to posebice dolazi do izražaja zbog vrhunskoga kritičkog aparata koji prati prijevod deftera. Knjiga sadržava 1139 bilježaka, u kojima se donose ubikacija onih mje- sta koje je bilo moguće ubicirati te identifikacija mnogih u defteru spomenutih građevina i podaci o značajnijim povijesnim ličnostima navedenima u njemu. Zemljovid osmanskomletačke granice na istočnom Jadranu nakon mira u Srijemskim Karlovcima s novom upravnom podjelom nahija Hercegovačkog sandžaka uvelike olakšava snalaženje u velikom broju u defteru navedenih geografskih pojmova. Već je navedeno da je ovaj defter jedini poznati izvor u kojemu se spominje nekoliko nahija privremeno uspostavljenih u pograničnom dijelu Osmanskog Carstva nakon Morejskog rata, ali i jedini izvor za određeni broj crkava i džamija do sada potpuno nepoznatih $u$ historiografiji, što pokazuje važnost ovoga kritičkog izdanja za administrativnu povijest $\mathrm{s}$ jedne strane te za vjersku povijest $\mathrm{s}$ druge. $\mathrm{K}$ tome, njegovu važnost za povijest stanovništva uistinu nije potrebno posebno naglašavati.

Objavljeni defter pokriva područje triju današnjih država - Hrvatske, Bosne i Hercegovine te Crne Gore - te je ovo izdanje doprinos njihovim nacionalnim historiografijama. Činjenica da je objavljivanjem ovog deftera nastavljeno objavljivanje protostatističkih izvora važnih za povijest habsburško-mletačko-osmanskog trograničja, započeto još 2003. izdavanjem $P$ opisa Like i Krbave 1712. godine, jasan je pokazatelj važnosti suradnje različitih institucija - iz više zemalja - u rasvjetljavanju povijesti hrvatskoga (ali i bosanskohercegovačkog i crnogorskog) ranonovovjekovlja.

Neven Kovačev 